DOE/PC/89772--T8

DE92 01.6124

\title{
APPLICATIONS OF MICELLAR ENZYMOLOGY TO CLEAN COAL TECHNOLOGY
}

Second Quarterly Report

DOE Grant No. DE-FG22-89PC89772

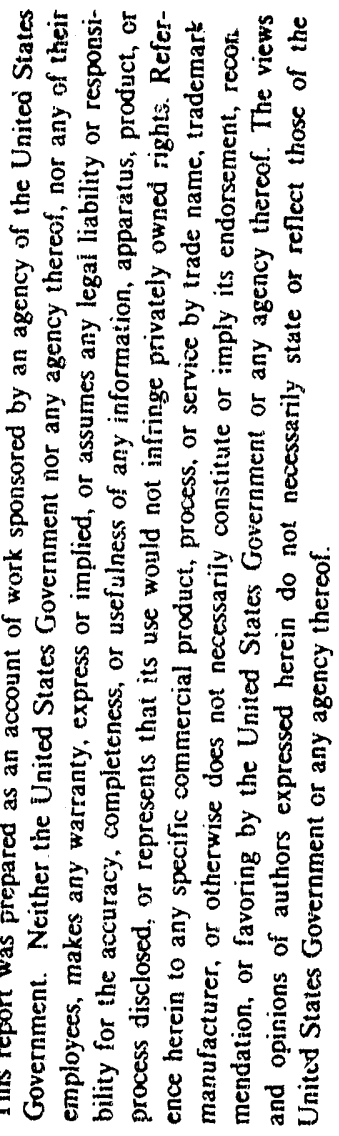

\author{
$15+2+21950$ \\ Submitted to: \\ Sayeed Akhtar \\ Technical Project Officer \\ PM-20, MS 922-206 \\ U.S. Department of Energy \\ Pittsburgh Energy Technology Center \\ P.O. Box 10940 \\ Pittsburgh, PA 15236 \\ Prepared by: \\ Carol T. Walsh, Ph.D. \\ Principal Investigator \\ Boston University School of Medicine \\ 80 E. Concord Street, L-603 \\ Boston, MA 02118 \\ 617-638-4326
}

April 27, 1990

US/DOE patent Clearance is not required prior to the publication of this document. 
TABLE OF CONTENTS

Section

Page

1

INTRODUCTION

1.1

Program Overview

1

1.2

Summary of Results

3

MATERIALS AND METHODS 3

2.1

Materials

2.2

Methods

4

2.2.1 Production of Reverse Micelle Solutions

2.2.2 Quantitative Analysis of DBT Metabolites: HPLC Procedure

Assay of Laccase in Aqueous and Reverse Micelle Solutions

RESULTS

3.1 Stability of Reverse Micelle Solutions of

AOT in Isooctane in Fresence of $\mathrm{HRP}$ and $\mathrm{H}_{2} \mathrm{O}_{2}$

3.2 HRP Activity in Reverse Micelle Solutions with DBT as Substrate

3.3 Activity of Laccase in Aqueous and Reverse Micelle Solutions 


\section{LIST OF FIGURES}

Figure

Page

Figure 1:

DBT and Metabolites in Sulfur Oxidation

Pathway

2

Figure 2:

HPLC Chromatogram of DBT and its Metabolites in $0.1 \mathrm{M}$ AO'T-Isooctane with $2.3 \% \mathrm{H}_{2} \mathrm{O}$

Figure 3:

Aqueous Laccase Assay (syringaldazine oxidation)

Figure 4:

Aqueous Laccase Assay (ABTS oxidation)

12

Figure 5:

Micellar Laccase Assay (ABTS oxidation)

\section{LIST OF TABLES}

Table 1:

Effect of 24-hr Incubation of DBT in HRP Reverse Micelle Solutions on HPLC Output of DBT 


\section{Section 1 \\ INTRODUCTION}

\subsection{Program Overview}

Full implementation of coal fuel sources will require more effective methods of providing "clean coal" as a fuel source. Methods must be developed to reduce the coal content of sulfur which significantly contributes to environmental pollution. This project is designed to develop methods for pre-combustion coal remediation by implementing recent advances in enzyme biochemistry. The novel appruact, of this study is incorporation of hydrophilic oxidative enzymes in reverse micelles in an organic solvent. Enzymes from commercial sources $\mathrm{cr}$ microbial extracts are being investigated for their capacity to remove organic sulfur from coal by oxidation of the sulfur groups, splitting of C-S bonds and loss of sulfur as sulfuric acid (Figure 1). Dibenzothiophene (DBT) and ethylphenylsulfide (EPS) are serving as models of organic sulfur-containing components of coal in initial studies.

A goal of this project is to define a reverse micelle system that optimizes the catalytic activity of enzymes toward desulfurization of model compounds and ultimately coal samples. Arnong the variables which will be examined are the surfactant, the solvent, the water:surfactant ratio and the $\mathrm{pH}$ and ionic strength of the aqueous phase. Studies by several groups (Martinek et aㅚ., 1981; Kabanov et al., 1988; Martinek, 1989; Verhaert et all., 1990) have shown that the strfactant AOT over a broad concentration range in organic solvents produces micelles, comparatively uniform in diameter, which incorporate hydrophilic enzymes. The activity (kcat) of certain enzymes in this system is higher than in aqueous solution. This surfactant is therefore being examined first, although the potential disadvantages of an $\mathrm{SO}_{3}$ containing molecule have been recognized. Other surfactants to be tested include Tritons, Tweens and Brij 35. 


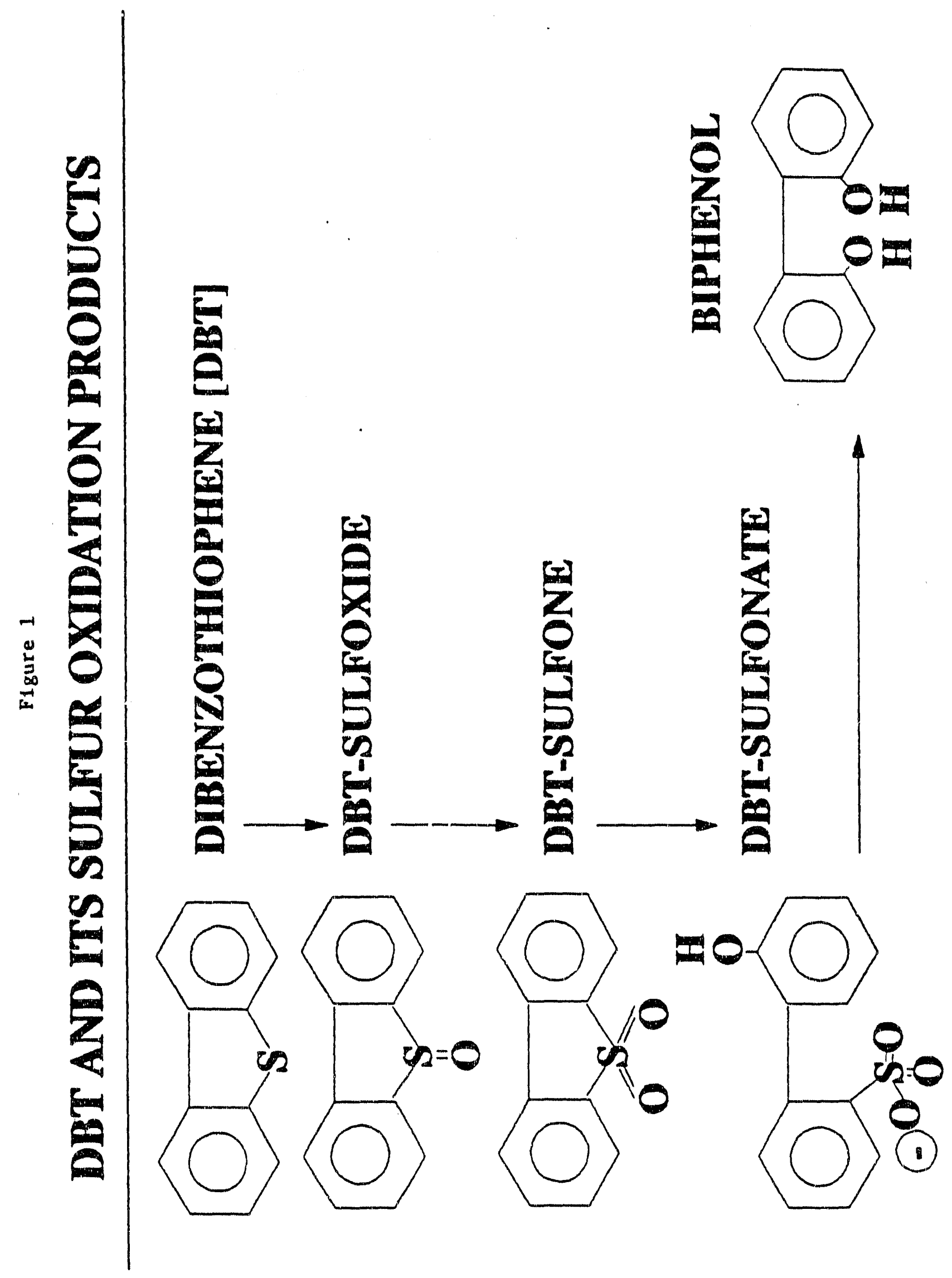




\subsection{Summary of Results}

The HPLC procedure for monitoring DBT and its sulfur oxidation products was modified to reduce the signal from the surfactant and its overlap with DBT sulfoxide. Initial studies with HRP in AOT-isooctane reverse micelles did not indicate production of sulfur oxidation products from DBT. One condition tested may have resulted in degradation of DBT by another pathway. The activity of laccase in aqueous solution has been characterized with several substrates. No or only negligible activity toward these substrates was detectable when the enzyme was solubilized in an AOT-isooctane reverse micelle solution.

\section{Section 2}

\section{MATERIALS AND METHODS}

\subsection{Materials}

Studies were carried out with HRP, Type I RZ $=1.20$ (Sigma Chemical Co.) and laccase from Pyricularia oryzae (Sigma Chemical Co.) Substrates for HRP assays included hydrogen peroxide $\left(\mathrm{H}_{2} \mathrm{O}_{2}, 30 \%\right.$, Fisher Scientific) and DBT (Aldrich Chemical). Substrates for assay of laccase activity were syringaldazine (Sigma Chemical Co.) and 2,2'azino-di(3-ethylbenzothiazoline-6-sulfonic acid) (ABTS, Sigma Chemical Co.). Metabolites of DBT used as standards in HPLC chromatograms included DBT sulfoxide (K\&K Laboratories), DBT sulfone (Aldrich Chemical Co.) and 2,2'-dihydroxybiphenol (Lancaster Synthesis Ltd.). Buffers included sodium phosphate (Fisher Scientific).

For formation of reverse micelle solutions the surfactant AOT, di(2-ethylhexyl)sodium sulphosuccinate, was obtained from Sigma Chemical Co. (The water content of the AOT has not been determined and therefore reported water content of micelle solutions do not account for the possible small contribution from this source.) Isooctane (Optima, Fisher Scientific) was used as organic solvent. 


\section{$2.2 \quad$ Methods}

\subsubsection{Production of Reverse Micelle Solutions}

AOT (MW 444) was dissolved in isooctane to produce a $0.1 \mathrm{M}$ solution. Aliquots of $0.025 \mathrm{M}$ phosphate buffer ( $\mathrm{pH} \mathrm{7.0)}$ were then added to the organic solution $(23 \mathrm{ul} / \mathrm{ml}$, 13:1 $\mathrm{H}_{2} \mathrm{O} \mathrm{AOT}$ ) and vortexed for $1 \mathrm{~min}$. For study of the 24-hr stability of the reverse micelle solution, dilutions of $\mathrm{H}_{2} \mathrm{O}_{2}$ in phosphate buffer were added to AOT-isooctane (23 $\mathrm{ul} / \mathrm{ml}$ ). For study of DBT in reverse micelle solutions, the compound was added to $0.1 \mathrm{M}$ AOT-isooctane. HRP and $\mathrm{H}_{2} \mathrm{O}_{2}$ were added in a total aqueous volume of $23 \mathrm{ul} / \mathrm{ml}$ solvent.

\subsubsection{Quantitative Analysis of DBT Metabolites: HPLC Procedure}

DBT (0.1-2 mM), DBT sulfoxide (0.02 mM), DBT sulfone $(0.02 \mathrm{mM})$ and dihydroxybiphenyl $(0.02 \mathrm{M})$ were added to $0.1 \mathrm{M}$ AOT in isooctane. To one $10-\mathrm{ml}$ aliquot, $0.23 \mathrm{ml}$ of $0.025 \mathrm{M}$ phosphate buffer was added to produce a reverse micelle solution. Samples were filtered through disposable syringe filter units (Rainin Instrument Co., No. 38-159, 0.2 u pore size, $3 \mathrm{~mm}$ diameter Nylon 66 membranes). Filtrates (4 ul) were analyzed at DynaGen, Inc. with a Waters HPLC system containing a C18 resolve (5 micron spherical) column. The mobile phase contained tetrahydrofuran:acetonitrile:water (23:20:57) at a flow rate of $1.5 \mathrm{ml} / \mathrm{min}$ (Experiment 1 ) or a programmed rate of $0.8-1.8$ $\mathrm{ml} / \mathrm{min}$ (Experiment 2). The specific program was $0.10 .5 \mathrm{~min}, 0.8 \mathrm{ml} / \mathrm{min} ; 10.5-27.0 \mathrm{~min}$, $1.8 \mathrm{ml} / \mathrm{min} ; 27.0 \mathrm{~min}-, 0.8 \mathrm{ml} / \mathrm{min}$. The detector was a Waters Lambda Max $481 \mathrm{LC}$ spectrophotometer which was set at $280 \mathrm{~nm}$. The method is a modification of procedures previously used by Dr. Kitchell at DynaGen, Inc. for analysis of DBT metabolites in organic solvents (Wyza et al., 1989).

\subsubsection{Assay of Laccase in Aqueous and Reverse Micelle Solutions}

The oxidative activity of laccase in aqueous and reverse micelle solutions was monitored by product formation from syringaldzaine (Harkin and Obst, 1973), or ABTS (Shin et al., 1987). 
For the syringaldzaine assay in aqueous solution, laccase was dissolved in $0.1 \mathrm{M}$ phosphate buffer ( $\mathrm{pH} 6.5$ ), a $0.5 \mathrm{ml}$ aliquot added to 1.5 of phosphate buffer and the solution incubated at $37^{\circ} \mathrm{C}$. Syringaldazine, $0.25 \mathrm{ml}$ of a $0.07 \mathrm{mg} / \mathrm{ml}$ methanol solution (21.6 uM final concentration), was then added, and the solution vortexed for $10 \mathrm{sec}$. Absorbance readings at $530 \mathrm{~nm}$ were monitored for $5 \mathrm{~min}$ with a LKB Model 4050 spectrophotometer linked to an IBM-compatible PC.

For the ABTS oxidation assay, $1 \mathrm{ml}$ of $0.55 \mathrm{mg} / \mathrm{ml}$ ABTS in phosphate buffer $(0.1$ $\mathrm{M}, \mathrm{pH} 6.5$ ) was diluted with $1.4 \mathrm{ml}$ of buffer and incubated at $37^{\circ} \mathrm{C}$. Laccase (100 ul, $2.8 \times 10^{-6} \mathrm{M}$ final concentration) was added. The absorbance was monitored at $740 \mathrm{~nm}$ for up to $10 \mathrm{~min}$.

Reverse micelle solutions of laccase were formed using $0.1 \mathrm{M}$ AOT-isooctane with addition of enzyme in 23 ul of phosphate buffer ( $\mathrm{pH} 6.5$ ) per ml of organic phase. Activity of the enzyme was then assessed by adding an equal volume of $0.1 \mathrm{M} \mathrm{AOT-}$ isooctane, containing 23 ul of substrate in phosphate buffer per $\mathrm{ml}$.

\section{Section 3}

\section{RESULTS}

\subsection{Stability of AOT-Isooctane Reverse Micelle Solutions in Presence of HRP and $\mathrm{H}_{2} \mathrm{O}_{2}$}

The 24-hr stability of 0.1 M AOT-isooctane solutions containing 13:1 $\mathrm{H}_{2} \mathrm{O}$ :AOT was examined by visual inspection and absorbance determinations in the wavelength range, 200-350 nm. The first series of experiments examined solutions containing 0-20 $\mathrm{mM} \mathrm{H}_{2} \mathrm{O}_{2}$ (no enzyme). The solutions containing $\mathrm{H}_{2} \mathrm{O}_{2}$ remained clear after $24-\mathrm{hr}$ at room temperature. The wavelength scan of AOT-containing solutions, measured against isooctane alone, exhibited a peak at $234 \mathrm{nM}$ with a rapid, linear drop to $255 \mathrm{~nm}$. After 24 $\mathrm{hr}$ the peak had dropped slightly, from 2.84 to 2.70 . In addition a significant increase in absorbance was observed from $255-300 \mathrm{~nm}$. This increase was inversely related to $\mathrm{H}_{2} \mathrm{O}_{2}$ concentration. 
This experiment was repeated with test solutions containing HRP $\left(2.1 \times 10^{-8} \mathrm{M}\right)$ and $\mathrm{H}_{2} \mathrm{O}_{2}(0.2-2.0 \mathrm{mM})$ or HRP alone. These samples were compared visually and spectrophotometrically to controls with neither $\mathrm{HRP}$ nor $\mathrm{H}_{2} \mathrm{O}_{2}$. All solutions remained clear for $24 \mathrm{hr}$. Wavelength scans were superimposable in all samples examined at 0 time and $24 \mathrm{hr}$, with peak absorbance at $234 \mathrm{~nm}$ of 2.86 absorbance units. The presence of HRP appeared therefore to prevent the changes in the wavelength scan of AOT observed after $24 \mathrm{hr}$ incubation with 0.2 and $2.0 \mathrm{mM} \mathrm{H}_{2} \mathrm{O}_{2}$ alone.

\subsection{HRP Activity in Reverse Micelle Solutions with TBT as Substrate}

DBT was incubated for $24 \mathrm{hr}$ with HRP in reverse micelle solutions; aliquots were analyzed by HPLC for DBT and the sulfur oxidation products, DBT sulfoxide, DBT sulfone and 2,2'-dihydroxybiphenol. In these experiments DBT was added to $0.1 \mathrm{M}$ AOT-isooctane to produce a final concentration of $2 \mathrm{mM}$. The aqueous phase $(23 \mathrm{ul} / \mathrm{ml})$ contained $\mathrm{H}_{2} \mathrm{O}_{2}$ alone ( 0.2 or $2 \mathrm{mM}$ final concintıation) or with $\operatorname{HRP}\left(2.1 \times 10^{-8} \mathrm{M}\right)$. Samples in duplicate were shaken 24-hr in 20-ml scintillation vials on a Scientific Industries rotator. Additional samples without DBT were run simultaneously to verify HRP activity as measured with the substrates, 4-aminoantipyrine and phenol. The procedure for this assay in reverse micelle solutions was described in the first quarterly report (2.2.3); an $\mathrm{HRP}, \mathrm{H}_{2} \mathrm{O}_{2}$-containing reverse micelle solution was combined with enzyme-containing micelle solutions at zero time or 24 hours.

The HPLC chromatographic output for $2.0 \mathrm{mM} \mathrm{DBT}$ and $0.02 \mathrm{mM}$ concentrations of each metabolite in the reverse micelle solution is illustrated in Figure 2. Changing the detection wavelength to $280 \mathrm{~nm}$ (from $242 \mathrm{~nm}$ ) markedly reduced the interference of AOT with the DBT sulfoxide peak (Figure 1, First Quarterly Report).

A summary of the first experiment is presented in Table 1. Except for one sample with $\mathrm{HRP}$ and $2 \mathrm{mM} \mathrm{H}_{2} \mathrm{O}_{2}$ (a result not replicated in the duplicate sample), there was no evidence of production of sulfur oxidation products under the conditions of this study. A decrease was noted in DBT concentration in the samples with $2 \mathrm{mM} \mathrm{H}_{2} \mathrm{O}_{2}$ and no HRP. 


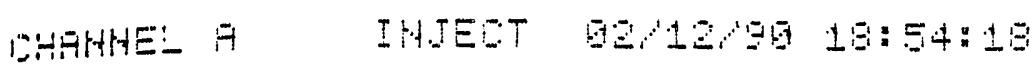

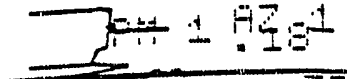
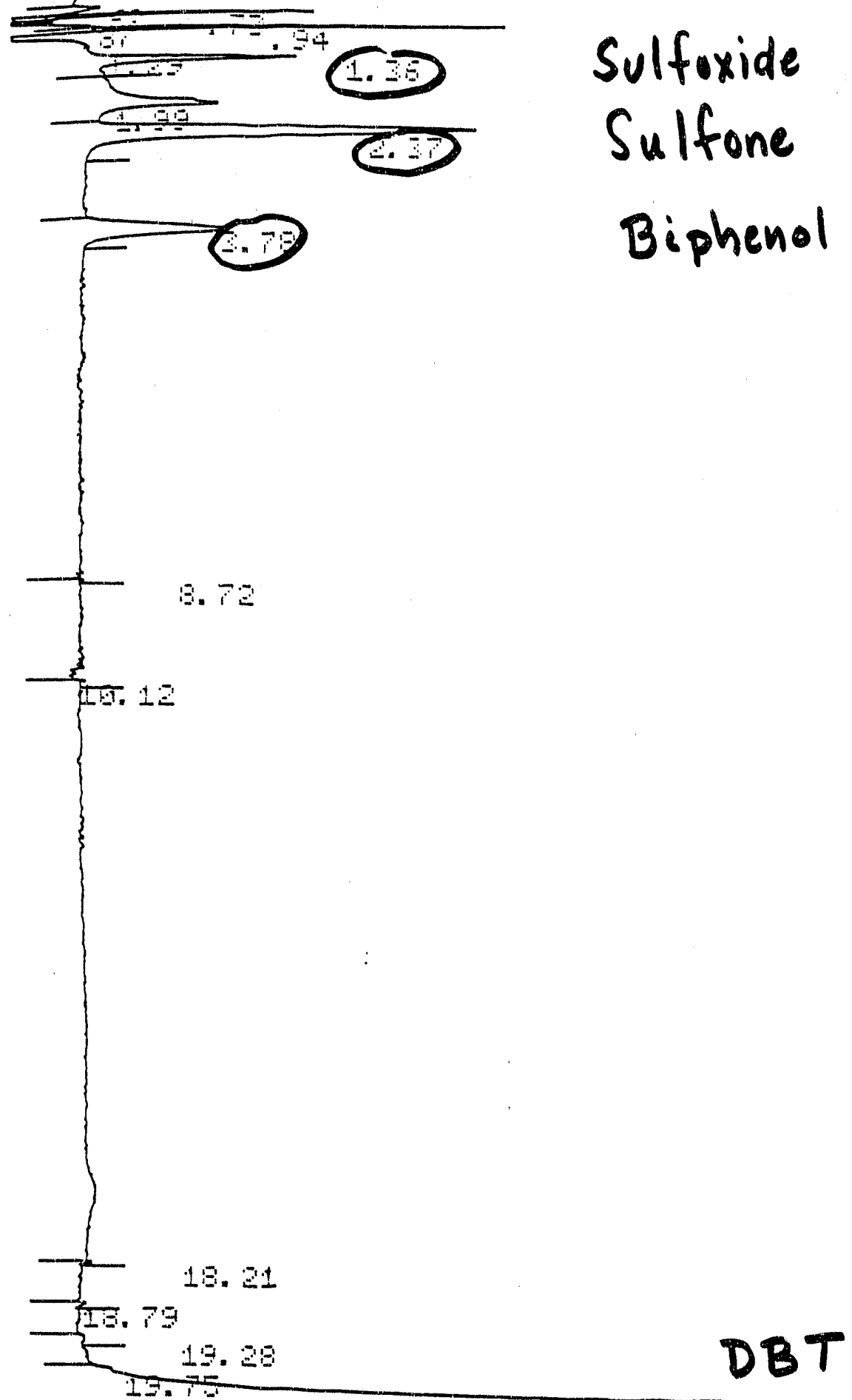
Table 1: Effect of 24-hr Incubation of

$2 \mathrm{mM}$ DBT in HRP Reverse Micelle Solution

(0.1 M AOT-isooctane, 13:1 H20:AOT)

on HPLC Output of DBT

DBT Area

$\left(\mathbf{x 1 0 ^ { 6 }}\right)$

Experiment 1

$\mathrm{H}_{2} \mathrm{O}_{2}(\mathrm{mM})$

$\operatorname{HRP}(\mathrm{M})$

\begin{tabular}{|c|c|c|}
\hline & 0 & $2.1 \times 10^{-8}$ \\
\hline 0 & $3.69 \pm 0.16$ & - \\
\hline 0.2 & $3.82 \pm 0.07$ & $3.72 \pm 0.17$ \\
\hline 2.0 & $3.38 \pm 0.02$ & $3.88 \pm 0.41$ \\
\hline
\end{tabular}

Experiment 2

$\mathrm{H}_{2} \mathrm{O}_{2}(\mathrm{mM})$

HRP (M)

$\begin{array}{llcc} & 0 & 2.1 \times 10^{-8} & 2.1 \times 10^{-6} \\ 0 & 3.66 \pm 0.17 & - & - \\ & 3.52 \pm 0.10\left(\mathrm{~N}_{2}\right) & & \\ & 3.22 \pm 0.09 & 3.47 \pm 0.024 & 3.64 \pm 0.03 \\ & 3.85 \pm 0.24\left(\mathrm{~N}_{2}\right) & 3.36 \pm 0.55\left(\mathrm{~N}_{2}\right) & 3.52 \pm 0.05\left(\mathrm{~N}_{2}\right)\end{array}$


If oxidation products were formed, they were not detectable by HPLC and were not sulfur oxidation products. It is conceivable that binding of $\mathrm{H}_{2} \mathrm{O}_{2}$ to HRP actually prevents the direct oxidation of DBT by $\mathrm{H}_{2} \mathrm{O}_{2}$.

Assay of this HRP preparation in reverse micelles with conventional substrates indicated oxidative activity of the enzyme at zero time with $0.2 \mathrm{mM} \mathrm{H}_{2} \mathrm{O}_{2}(0.013 \pm 0.002$. abs. units/min), but not the $2.0 \mathrm{mM}$ concentration. By $24-\mathrm{hr}$, the $0.2 \mathrm{mM} \mathrm{H}_{2} \mathrm{O}_{2}, \mathrm{HRP}$ solution no longer demonstrated activity, presumably due to consumption of $\mathrm{H}_{2} \mathrm{O}_{2}$.

In a subsequent study with DBT (Experiment 2, Table 1), reverse micelle samples contained $0.2 \mathrm{mM} \mathrm{H}_{2} \mathrm{O}_{2}$ with or without HRP $\left(2.1 \times 10^{-8} \mathrm{M}\right.$ or $\left.2.1 \times 10^{-6} \mathrm{M}\right)$. Replicates of each condition were flushed with $\mathrm{N} 2$ to reduce atmospheric oxygen-dependent degradation of $\mathrm{H}_{2} \mathrm{O}_{2}$. For only one condition, the higher enzyme concentration (without $\mathrm{N}_{2}$ ), was there reproducible evidence of a sulfur oxidation product, the sulfoxide, although levels were extremely low (areas about $2.5 \%$ of that for $0.1 \mathrm{mM} \mathrm{DBT}$ sulfoxide).

\subsection{Activity of Laccase in Aqueous and Reverse Micelle Solutions}

The formation rate of semiquinone from syringaldazine $(21.6 \mathrm{uM})$ in aqueous solution $(0.1 \mathrm{M}$ phosphate buffer) increased linearly with the concentration of laccase $(0.38$ - $3.56 \times 10^{-6} \mathrm{M}$ ) (Figure 3). Laccase in $0.1 \mathrm{M}$ phosphate buffer was added to $0.1 \mathrm{M}$ AOTisooctane $(23 \mathrm{ul} / \mathrm{ml})$ to a final concentration of $1.52 \times 10^{-6} \mathrm{M}$. Syringaldazine $(0.07 \mathrm{mg} / \mathrm{ml}$ methanol diluted 1:9 in phosphate buffer $)$ was added to $0.1 \mathrm{M}$ AOT-isooctane $(23 \mathrm{ul} / \mathrm{ml})$. Both solutions were heated to $37^{\circ} \mathrm{C}$. Equal amounts were combined and absorbance monitored for $5 \mathrm{~min}$ at $530 \mathrm{~nm}$. No activity was detectable. Addition of larger volumes of enzyme and substrate-containing aqueous phases to AOT-isooctane $(32.5 \mathrm{ul} / \mathrm{ml})$ also resulted in no activity. Attempts to dissolve syringaldazine into isooctane at $21.6 \mathrm{uM}$ or into buffer without methanol were unsuccessful. Use of 85 -fold higher concentrations of syringaldazine in methanol in an attempt to achieve a $21 \mathrm{uM}$ final concentration caused precipitation after addition to AOT-isooctane. Laccase activity in reverse micelles was also examined using $0.025 \mathrm{M}$ rather than $0.1 \mathrm{M}$ phosphate buffer ( $\mathrm{pH}$ 6.5). A 10-fold higher 


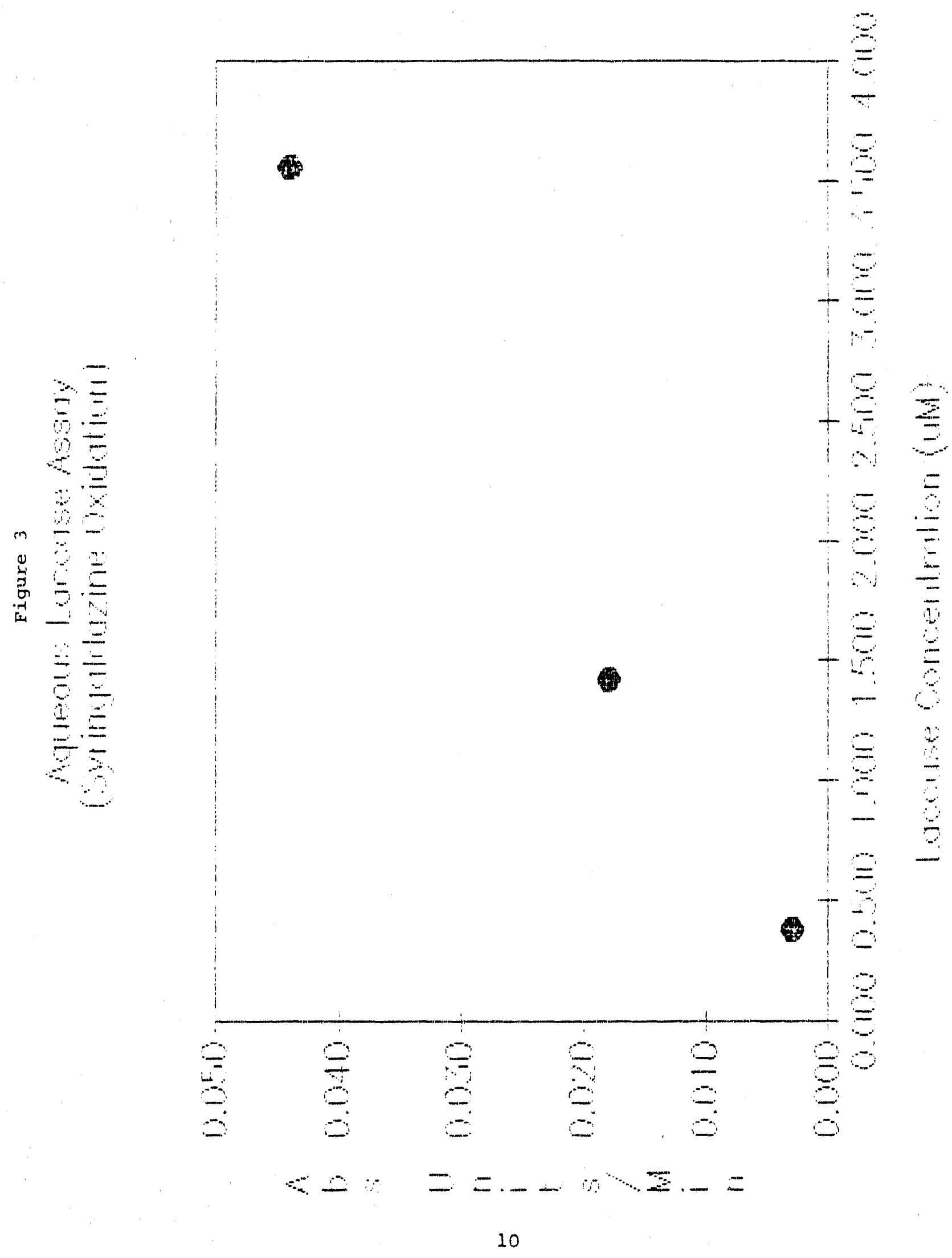


syringaldazine concentration in buffer was used; no precipitation occurred in AOT. isooctane. Activity was not detectable. The same enzyme preparation assayed in aqueous solution gave results $(0.011$ abs. units/min) comparable to earlier experiments $(0.017$ abs. units/min).

Because of the solubility limits of syringaldazine, studies were carried out with another substrate, ABTS (Shin et al., 1987). This compound is oxidized by laccase to a molecule with an absorbance peak at $737 \mathrm{~nm}$. The formation of product by $2.8 \times 10^{-6} \mathrm{M}$ laccase increased with incubation time (Figure 4). A linear increase in the product was demonstrated for enzyme concentrations of $1.1 \times 10^{-7}-2.8 \times 10^{-6} \mathrm{M}$. Activity of laccase in AOT-isooctane reverse micelles was studied with ABTS as substrate. Enzyme concentrations were $3.3 \times 10^{-8} \mathrm{M}$ and $3.3 \times 10^{-7} \mathrm{M}$. The ABTS concentration (added in $\mathrm{pH}$ $6.5,0.025 \mathrm{M}$ phosphate buffer) was $0.032 \mathrm{mg} / \mathrm{m}$ !; the substrate did not dissolve in isooctane at concentrations twice those "sec in the aqueous assay. No activity was detected with the lower enzyme concentration. With the higher enzyme concentration, some activity was detected and was greater in tubes vortexed every 2 min during the 10-min reaction (Figure 5). The absorbance at $740 \mathrm{~nm}$ increased from 3 to 10 minutes, although not linearly. The wavelength scan of the solution after $10 \mathrm{~min}$ did not show the peak at $740 \mathrm{~nm}$ (greenish tint) present in the reaction carried out under aqueous conditions. Increasing the size of the micelles by increasing the aqueous volume to $35 \mathrm{ul} / \mathrm{ml}$ did not enhance the activity.

\section{PLANS FOR THE THIRD QUARTER}

1. Study of the effect of a more active preparation of HRP (Type VI, RZ $=3.1$ ) in reverse micelles on DBT and EPS. Comparison of HRP activity will be made using micelles from the surfactants, AOT, Triton X-100 and CTAB.

2. Assay of laccase activity in revirse micelles with a substrate more soluble in the organic phase. Recent publications (Martinek, 1989; Pshezhetskii ef all., 1988; Mozhaev et al., 1989) indicate the utility of pyrocatechol as substrate in assessment of laccase activity in reverse micelles or water-organic solvent mixtures. A laccase of higher activity (from 


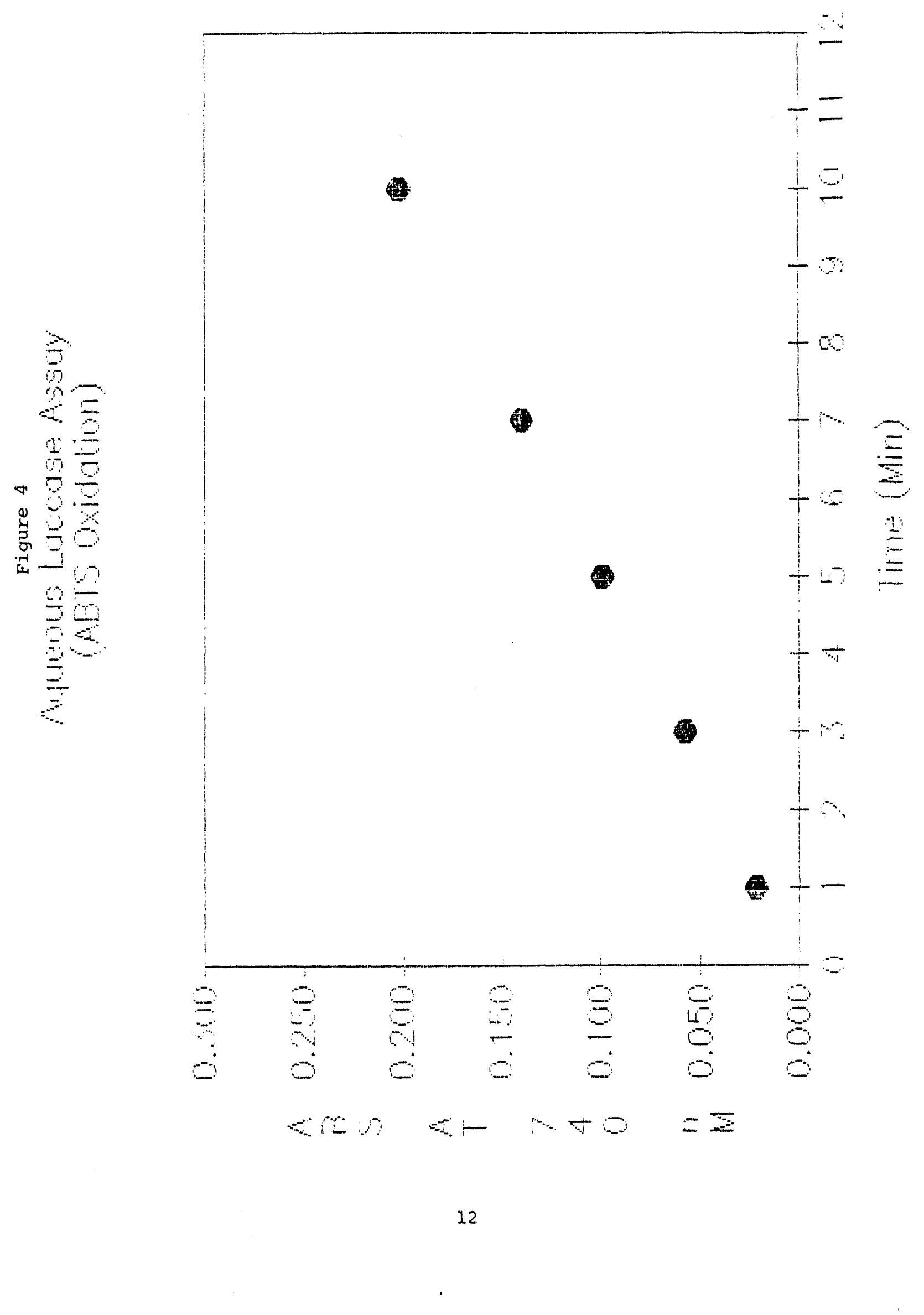




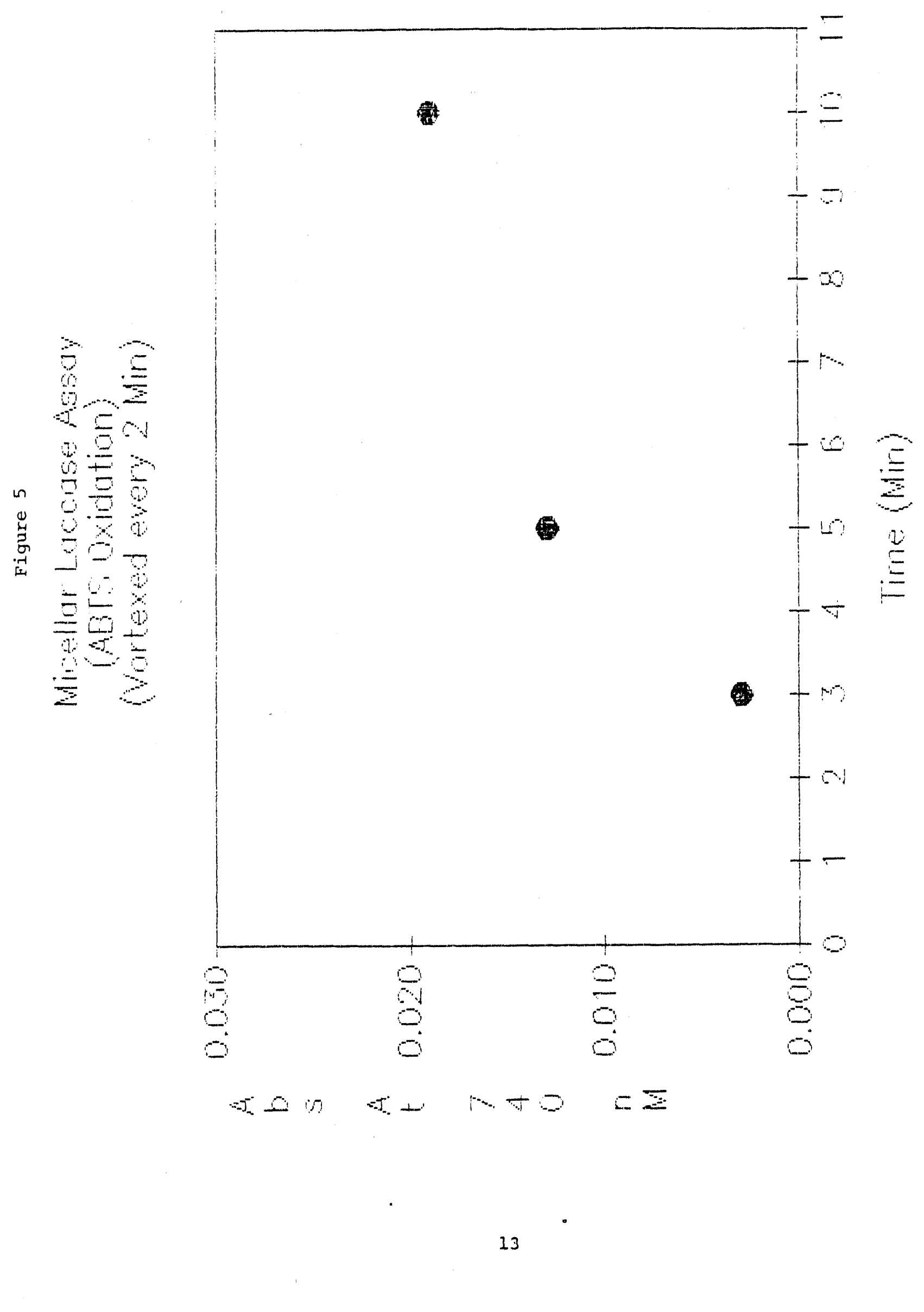


Polyporus versicoior; Reinhammar, 1984) will be investigated using first pyrocatechol and then DBT and EPS.

\section{BIBLIOGRAPHY}

Harkin, J.M. and Obst, J.R. Lignification in trees: indication of exclusive peroxidase participation. Sciençe 180: 296-298, 1973.

Kabanov, A.V., Levashov, A.V., Klyachko, N.L., Namyotkin, S.N., Pshezhetsky, A.V. and Martinek, $\mathrm{K}$. Enzymes entrapped in reversed micelles of surfactants in organic solvents: a theoretical treatment of the catalytic activity regulation. J. Theor. Biol. 133: 327-343, 1988.

Lee, K.-I. and Yen, T.F. Coal desulfurization through reverse micelle biocatalysis process. Proceedings of ACS Meeting, San Francisco, CA, 1988, pp. 573-579.

Martinek, K. Micellar enzymology: potentialities in fundamental and applied areas. Biochemistry International 18: 871-893, 1989.

Martinek, K., Levashov, A.V., Klyachko, I!.L., Pantin, V.I. and Berezin, I.V. The principles of enzyme stabilization vs. catalysis by water-soluble enzymes entrapped into reversed micelles of surfactants in organic solvents. Biochim. Biophys. Acta 657: 277-294, 1981.

Martinek, K., Berezin, I.V., Khmelnitski, Y.L, Klyachko, N.L. and Levashov, A.V. Coll. Czech. Chem. Commun. 52: 2589, 1987.

Mozhaev, V.V., Khmelnitsky, Y.L., Sergeeva, M.V., Belova, A., Klyachko, N., Levashov, A. and Martinek, $\mathrm{K}$. Catalytic activity and denaturation of enzymes in water/organic cosolvent mixtures. Eur. J. Biochem. 184: 597-602, 1989.

Pshezhetskii, A.V., Merker, S., Pepanyan, G.S., Llyachko, N.L., Martinek, K. and Levashov, A.V. Modelling of the membrane environment of enzymes: superactivity of laccase entrapped into surfactants reversed micelles in organic solvents. Biokhimiya (Moscow) 53(6): 1013-16, 1988. 
Reinhammar, B. Laccase. In: Copper Proteins and Copper Enzymes, Vol. III, Lontie, R., ed., CRC Press, Inc., Boca Raton, FL, 1984.

Shin, T., Murao, S. and Matsumura, E. A chromogenic oxidative coupling reaction of laccase: applications for laccase and angiotensin I converting enzyme assay. Anal.

Biochem. 166: 380-388, 1987.

Verhaert, R.M.D., Hilhorst, R., Vermue, M., Schaafsma, J.J. and Veeger, C.

Description of enzyme kinetics in reversed micelles. 1. Theory. Eur. J. Biochem. 187: 59. $72,1990$.

Wyza et al. Presented at Microbial Coal Desulfurization Workshop, DOE Contractors Review Meeting, August, 1989. 


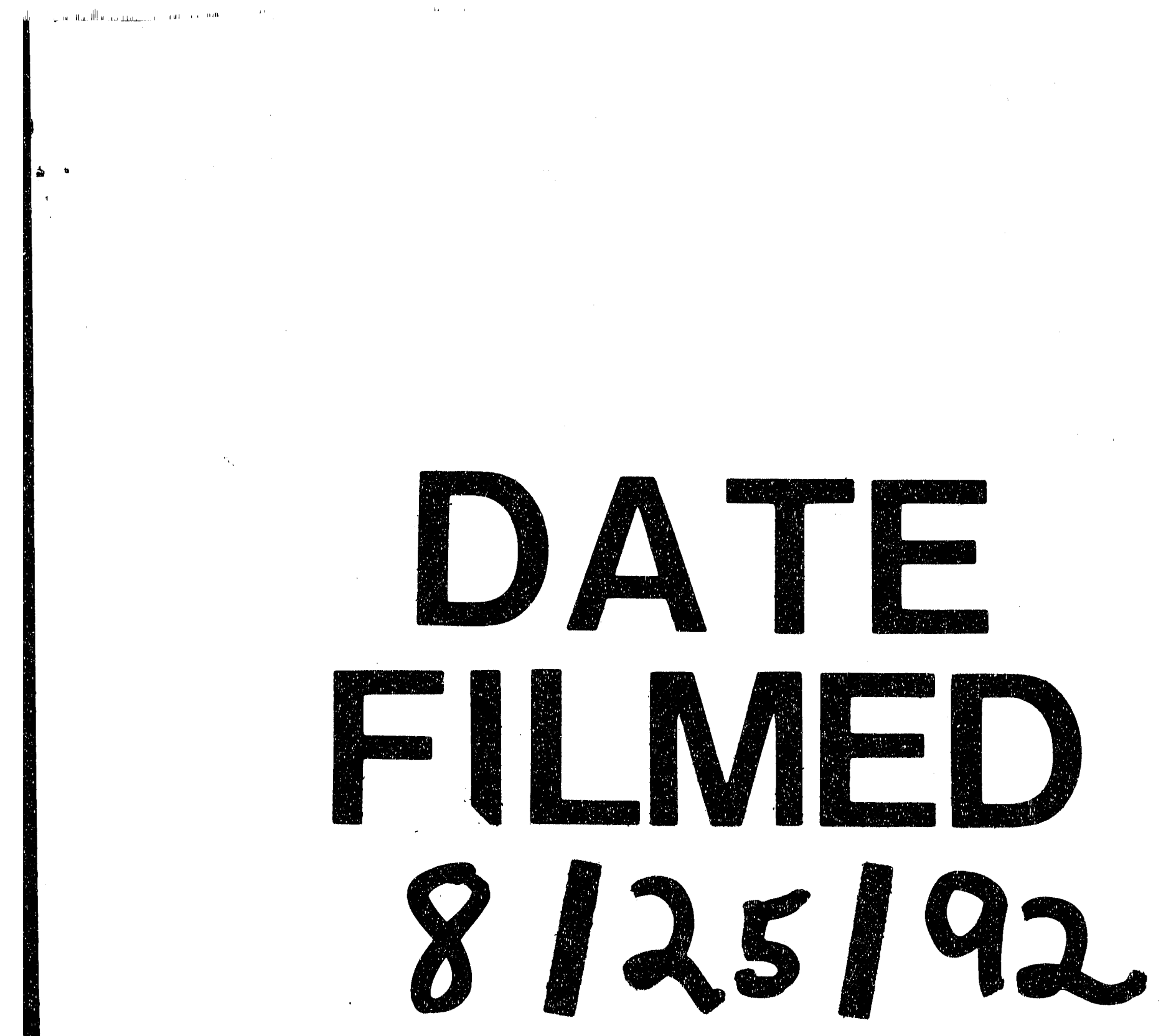


